\title{
A framework to create employability skills for small and medium scale industry
}

\author{
Vaibhav Gandhi ${ }^{1}$, Parag Paija ${ }^{2}$, Tarang Joshi ${ }^{3}$, Jay Vekariya ${ }^{4}$, Priyank Zaveri ${ }^{5}$, Vimal N. Patel ${ }^{6}$ \\ ${ }^{1}$ Professor, Department of MCA, B H Gardi College of Engineering and Technology \\ ${ }^{2,5}$ Assistant Professor, Department of Mechanical Engineering, B H Gardi College of Engineering and Technology \\ ${ }^{3}$ Assistant Professor, Department of Electrical Engineering, B H Gardi College of Engineering and Technology \\ ${ }^{4}$ Assistant Professor, Department of Civil Engineering, B H Gardi College of Engineering and Technology \\ ${ }^{6}$ Professor, Department of Civil Engineering, B H Gardi College of Engineering and Technology
}

\begin{abstract}
Many recent surveys in India are proving a huge gap between industry expectations from engineering students and students' employability skills. These surveys had majorly focused on employability skills required for MNCs but not been catered for SMEs and MSMEs of rural area. We are focusing on employability skills required for SMEs and MSMEs in the local region. Even the Indian government is promoting AtmaNirbhar Bharat scheme under which there will be a huge demand for skilled engineers in the local region. Authors are in connection with industries in the local region and prepared a framework to fill the gap between local industries and Engineering Institutes situated in a rural area. Our framework helps engineering students and faculty members to work on industry assigned work which will sharpen their skills required by industry. Our framework is solving burning issues like employability of engineers, lack of manpower for local SMEs and MSMEs and placements for institutes situated in remote areas. Even working with local industry during study inculcates seeds of entrepreneurship in students' minds.
\end{abstract}

Keywords: Industry Institute Interaction, Skill enhancement, Engineers for SMEs and MSMEs, engineering education, employable engineer, entrepreneurship, consultancy

\section{Corresponding Author}

Dr Vaibhav Gandhi

Professor \& Head,

Department of MCA| Department of IT Engineering

Email: gandhi.vaibhav@gmail.com

\section{Introduction}

For the betterment of any industry, development of their employees is a key factor. Industries are focusing on employees with various employability skill sets. Employability skills are the skills are the basic skills required for an engineer to be employed in any industry. Along with a good technical knowledge industry also demands a set of skills which are necessary for better performance of an employee in the described job profile. (Nicholas D. Rhew, 2019)An engineer needs different managerial skills as well as various technical skills. Skill sets required by the various types of industries differ at each level. Skill sets required by the MNCs are not always suitable for SMEs and MSEs. (Mohd Yusof Husain, 2010)

Through education and training one can transfer knowledge, proficiency and skills sets needed by an industry. Industries are doing hard practices to be in a good position in the market. To achieve their goal of success industry demands an employee with various employability skills and abilities. Also the cost of human development is increasing day by day so industries are expecting education institutes to produce industry ready graduates with the necessary employability skill sets and industries need not to give additional training to their employees. Therefore engineers with employability skills will have favourable situations to be absorbed by the industry. (J. Kavitha, 2019)

It is always expected that students should be developed in three domains: Knowledge, attitude and Skills. Generally, faculties are inculcating knowledge as per the guidelines given by their respective university. Attitude is built up by encouraging students to participate in different technical and non-technical events. The Skill domain is untouched so far by almost all major institutes. Engineering graduates which are the outputs of engineering institutes are the resources for the industrial sector. (Corporate, 2019)

Engineering educational institutes are expected to focus and engage students with contemporary world issues. Industries 
are always demanding to invest in personal skills for the overall development of industry as well as the personal. (Chithra, 2013) However, engineering institutes are criticized for not producing industry ready graduates. Thus various attempts have been made by these institutes to meet those challenges. (Marta Abelha, 2020) A report of Higher Education Academy, brings to attention the effective strategies that can be acquired by higher educational institutes. This approach also strengthens the authorities of engineering educational institutions in the overall development of students. Engineering institutes plays a pivotal role for the development of nation's economy. (Ugochukwu Chinonso Okolie, 2020)

The MSMEs in India are playing a pivotal role by generating a large number of opportunities at less investment compared with large scale industries. MSMEs are the first layer in the operation industry in our country and they are preferring locations in rural areas which will lead to regional imbalance, national income will be equally distributed. Being the first layer of the system their capabilities are considerable. So development of MSMEs plays an important role in the overall growth of the country. MSMEs of Gujarat region are outstandingly determined by the current global trends and national economy related to business performance. (Ministry, 2020)

Authors had studied availability of SMEs and MSMEs in Gujarat state and skill set require by them from specifically in Saurashtra Region of Gujarat state. As per the report published by MSME commissionerate, there are a total of 781635 units registered in Gujarat state and 15735777 employment generated through MSMEs. Specifically in Saurashtra region which comprises Rajkot, Jamnagar, Morbi, Junagadh, Porbandar \& Bhavnagar district have $81338,11356,7073,5865,1663,18933$ units of MSMEs.1 Share of rural area is $51 \%$ and urban area is $49 \%$ as seen in table-1 (Coommissionerate, 2020)

\begin{tabular}{|c|c|c|c|c|c|}
\hline Sector & Micro & Small & $\begin{array}{l}\text { Medi } \\
\text { um }\end{array}$ & $\begin{array}{l}\text { Total } \\
\text { Units } \\
\text { (in }\end{array}$ & Share \\
\hline lakh) & \\
\hline Rural & 324.09 & 0.78 & 0.01 & 324.88 & 51 \\
\hline Urban & 306.43 & 2.53 & 0.04 & 309.00 & 49 \\
\hline & 630.52 & 3.31 & 0.05 & 633.88 & 100 \\
\hline
\end{tabular}

Table 1 Statistics of MSMEs in Rural \& Urban Area in Gujarat state

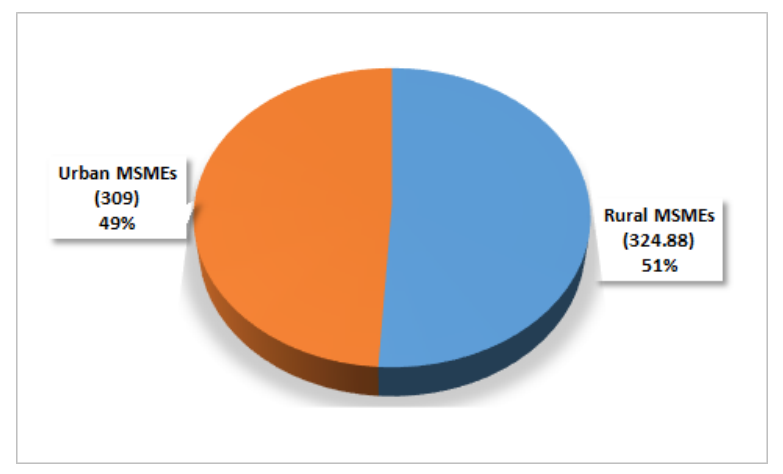

Figure 1 Availability of MSMEs in Rural and Urban area

\section{Atmanirbhar Bharat:}

On 12 May 2020 the Prime Minister of India, Mr. Narendra Modi, declared a special economic package of Rs 20 lakh crore (equivalent to $10 \%$ of India's GDP) with the purpose of making the country self-reliant against the robust competition in the global supply chain and to help in empowering the lower standard people, labourers, migrants who have been adversely affected by COVID. Following this announcement, the Finance Minister, Ms. Nirmala Sitharaman, through five press conferences, announced detailed measures under the economic package. (MyGov, 2020)

In the AtmaNirbhar Bharat (Self-Reliant India) Indian Government has given the importance of MSMEs for the Indian economy, the Rs 3 lakh core collateral-free loan facility for MSMEs under the package will help this finance-starved sector and thereby provide a kick start to the unfortunate state of the economy. This scheme will definitely boost SMEs and MSME companies and it is expected that huge number of new companies will be established in India.

\section{Current engineering curriculum in India:}

Engineering educational institutes should prepare graduates as per the knowledge and skills required by the SMEs \& MSMEs. Engineering graduates should be able to tailor engineering solutions for the various aspects in the growth of industry. By keeping this in mind education institutes should train and educate the students. (Ashish Kumar Parashara, 2012) SMEs \& MSEs industries of India are competing globally in everything starting from automobiles, textiles, ceramics, chemicals and many more. Growth of engineering institutes can lead India for a huge success.

Higher education institutes which are producing engineering graduates need to take a review of their current courses in comparison with industrial skill requirements. (Selvasundaram, 2016)

Engineering educational institutes should keep an eye on the future skill requirements of the industry and accordingly make necessary changes for the undergraduate students to be equipped with the right industrial skills. (Anna L Carew, 2008) Hence engineering institutes should develop an instrument for the periodic feedback from industrial experts 
to know about the development in technology and required skills for the same.

As per current engineering education students are less focused towards skills required for industries. Few tire 1 colleges of metro cities are preparing students for MultiNational Companies (MNCs) but majority colleges of tire 2

\section{Survey of industries in Saurashtra Region}

Authors have surveyed 150+ MSMEs which are located in Saurashtra region and identified more than 100+ skills from various domains which they are expecting from an engineering graduate. Authors have also surveyed types of

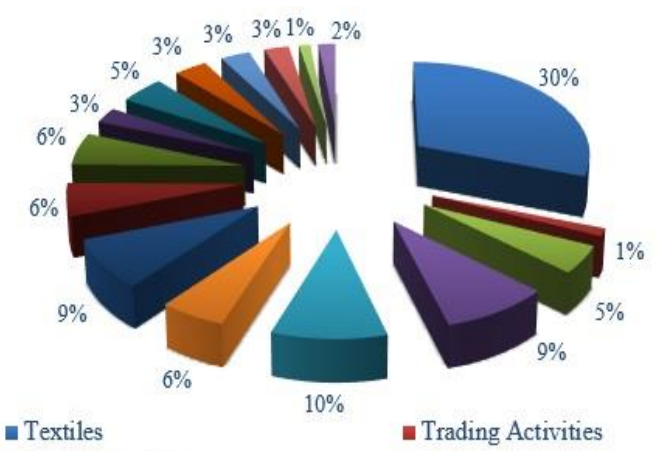
- Service Activities
- Machinery and parts except electrical
- Basic Metal Industries
Other
- Rubber \& Plastic Products
-Electrical Machinery and Apparatus
- Paper Product \& Printing
- Mining and Quarrying
- Transport equipment and parts

and tire 3 cities are not having such practices. Majority companies in tire 2 and tire 3 cities and their nearby area are SMEs and MSMEs only. So it is expected that students studying in engineering colleges near to such industries should be skilled enough to serve in those industries.

industries available in the local region which are graphically represented in fig. -1 Based on skills identified from industry experts are listed in table-2. gears \& diverse instruments but if they want to construct a Gear then they require some skills like AutoCAD, measurement and manufacturing. they are required to be practiced for enhancements of hands-on skills. So we need to map Industry Skills with Syllabus for effective learning \& growth. Thus, for development in industries, we have to develop \& enhance the gap analysis skills required for industries from theoretical \& practical skills which would lead to enhance \& develop diverse skills.

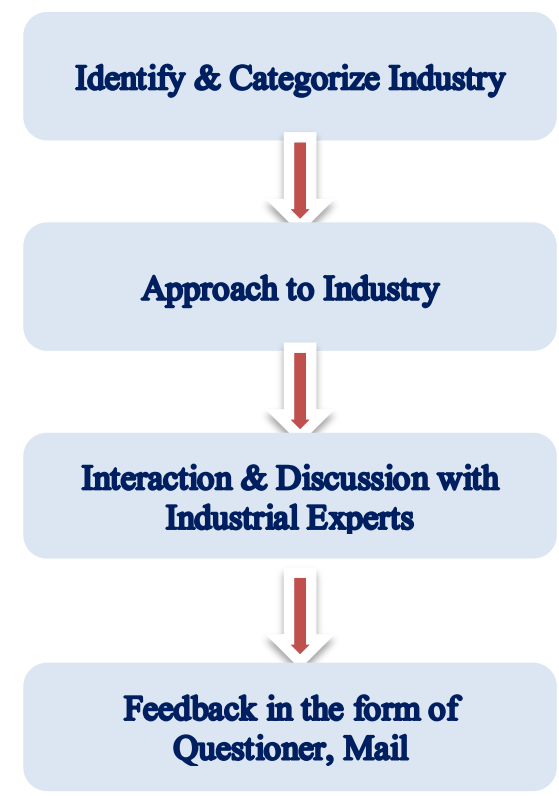


Figure 3 Process flow of survey and analysis

In our survey of 150+ industries, we found 20+ domains from Mechanical, Electrical and Civil engineering related industries. From these all domains, we identify list of 200+ skills expected from industries located in our nearby region. We have categorized all skillset expected from industries such that we can map each skill with at least one subject of engineering education. In below table 2, we have shown example of 3 such area where we have mapped machine design software, measurement, calibration, operation and maintenance related skills into various subjects of mechanical engineering. 10+ industries have agreed upon to give work related to these skills to our students and staff. In laboratory of our engineering college, our faculties and students will complete work assigned by industries. This is starting of consultancy work where engineering college students and staff members will be working in college laboratory for tasks assigned by industries. All stack holders like students, staff members, college management and industries will be having advantages of this eco system.

\begin{tabular}{|c|c|c|c|}
\hline Sr. No & Domain/Area & Required Skills & Mapped University Course \\
\hline 1 & Machine Design Software & $\begin{array}{l}\text { 3D Modelling (AutoCAD Creo, } \\
\text { - Solidworks, NX) } \\
\text { - Analysis (ANSYS) Softwares }\end{array}$ & $\begin{array}{l}\text { - Machine Design \& Industrial } \\
\text { Drafting } \\
\text { - Engineering Graphics \& } \\
\text { Design } \\
\text { - Finite Element Method }\end{array}$ \\
\hline 2 & Measurement \& Calibration & $\begin{array}{l}\text { - Linear Measurement \& Angular } \\
\text { - } \quad \text { Measurement } \\
\text { - Calibration (pH meters, Proving } \\
\text { ring, Pressure gauge, Slip gauge, } \\
\text { Thermometer, Thermocouple) }\end{array}$ & $\begin{array}{l}\text { Mechanical Measurement } \\
\text { and Metrology } \\
\text { Advance Manufacturing \& } \\
\text { process technique }\end{array}$ \\
\hline 3 & Operational \& Maintenance & $\begin{array}{l}\text { - } \text { Basic Machine Tools } \\
\text { - Advanced Machine Tools } \\
\text { - Non-Conventional Machine } \\
\text { - Tools } \\
\text { - Fabrication }\end{array}$ & $\begin{array}{l}\text { - Production Technology and } \\
\text { Manufacturing Process }\end{array}$ \\
\hline
\end{tabular}

Table 2 Mapping of Skills Vs Subject in Engineering Course

\section{Proposed Framework}

To reduce the skill gap authors have proposed a framework which will be useful to SMEs \& MSMEs, students, faculties, management and the overall ecosystem for the benefit of all. In the proposed framework engineering institute faculties and students need to visit nearby industries. Institute need to understand exact skillset require by nearby industries. While preparing list of industry for visit, institute need to take care for versatility in industry selection so that institute can have almost all skillsets require in their nearby region. Institute need to prepare questionnaires, survey form and then need to have one to one meeting with industry owner and senior managers. Local industries SMEs \& MSMEs need to be motivated to identify points like required skills and other support in terms of require resources.

From the educational institutes end they need to identify the courses that can be mapped with industry requirements and from that they need to perform gap analysis between skills requirements from the industry side with their university courses. Based on the gap analysis, institutes should redesign the experiments to fill the gap. It might be possible that institutes need more infrastructure / instrument to fulfil the requirements demanded from the industries. Based on the available resources institutes can start consultancy work. In some cases, institutes' facilities or faculties need authorization certificates from accreditation bodies like NABL, ISO, BEE for energy audits, etc. This certification again helps and motivates institutes for more consultancy work.

Outcome of proposed framework

Outcomes of framework are as below,

- As engineering institutes working on skills development of undergraduate students' employability can be reduced significantly.

- With work in industry students can earn while they are in the learning phase.

- As small engineering institutes are also developing infrastructure / instruments required by the industry they can start consultancy.

- More utilization of college laboratory and infrastructure

- Entrepreneurship in students

- Overall quality development of students

- Students are getting skills required by industry, they are first choice of industry for placements. 


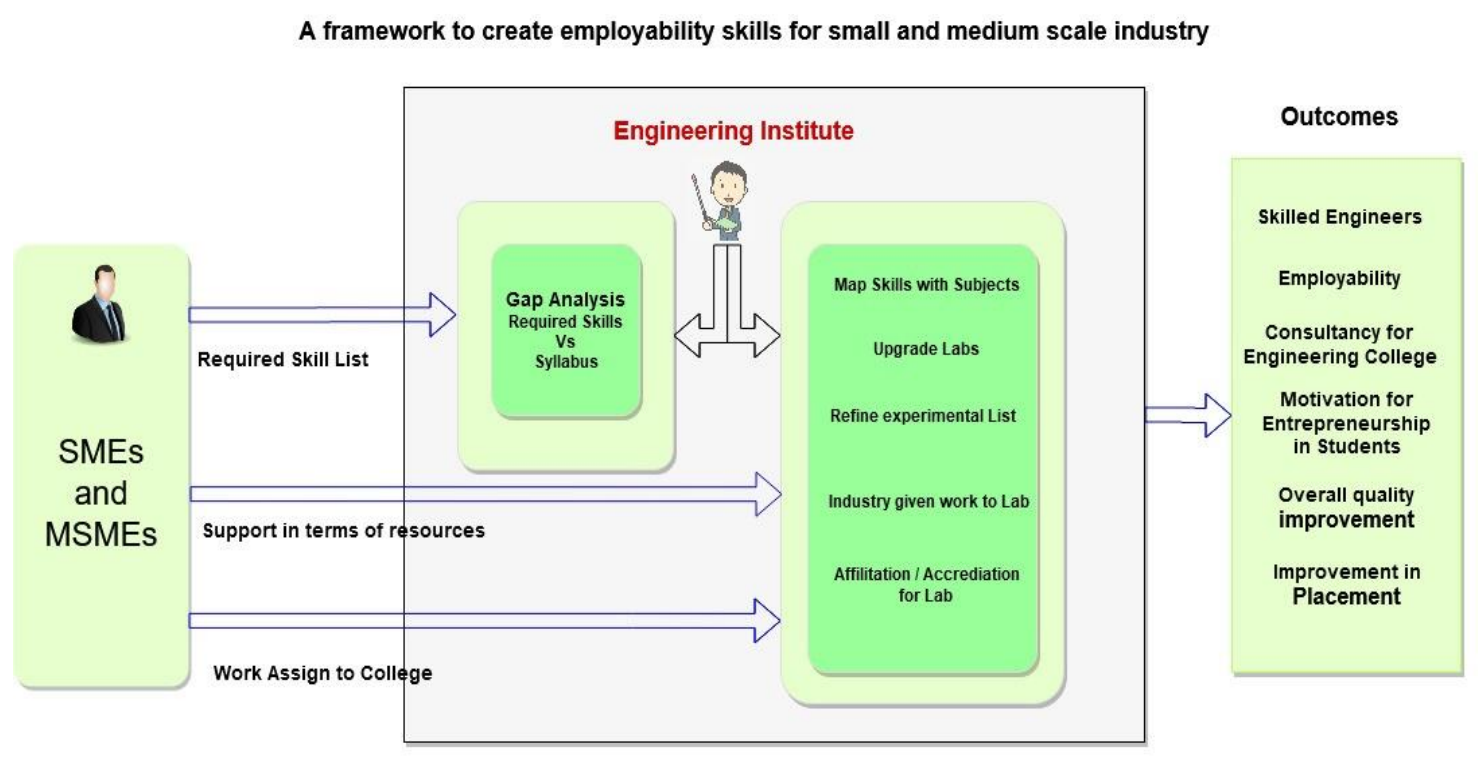

Figure 4 Framework for enhancing employability skills for SMEs and MSMEs

\section{Conclusion:}

We have taken a survey of nearby local industries and based on that we prepared our required analysis for inculcating require skills in engineering students. Based on the gap analysis of required skills and prevailing syllabus, students can be trained to fill the gap for their personal and professional development. Our framework can be extended by any other college in any region. They need to survey for required skillsets for their nearby industries. Institutes can develop various technical facilities at their premises. The key outcome of our framework is employable engineers for surrounding region SMEs and MSMEs. Our framework will help to any engineering colleges to have skilled engineers, more employability, earning for all stack holders, improvement in placement and more entrepreneurship skills in engineering graduates.

\section{References}

Anna L Carew, P. C. (2008). Engineering curriculum review:. Annual SEFI Conference.

Ashish Kumar Parashara, R. (2012). Innovations and Curriculum Development for Engineering Education and Research in India. International Conference on Teaching and Learning in Higher Education (ICTLHE 2012) in conjunction with RCEE \& RHED 2012, (pp. 685-690).

Chithra. (2013). Employability Skills -A Study on the Perception of the Engineering Students and their Prospective Employers. Global Journal of Management and Business Studies, 3, 525-

534.

Coommissionerate, M. (2020). District Wise UAM. Udyog

Bhavan, Gandhinagar. Retrieved 2020, from

https://msmec.gujarat.gov.in/statastics

Corporate, W. (2019). India Skills report. Wheebox Corporate office.
J. Kavitha, N. (2019). Employability Skill Gap Analysis Among the Engineering Students and Industry Expectation in Chennai with Structural Equation Model. International Journal of Innovative Technology and Exploring Engineering.

Marta Abelha, S. F.-O. (2020). Graduate Employability and Competence Development in Higher Education-A Systematic Literature Review Using PRISMA. sustainability.

Ministry, M. S. (2020, 09). 1. Retrieved from 1: https://msme.gov.in/vibrant-gujarat-article

Mohd Yusof Husain, S. B. (2010). Importance of Employability Skills from Employers' Perspective. International Conference on Learner Diversity 2010, (pp. 430-438).

MyGov. (2020, 09). 01. Retrieved from Atmanirbharat Abhiyan: https://aatmanirbharbharat.mygov.in/

Nicholas D. Rhew, J. A. (2019). Are we teaching what employers want? Identifying and remedying gaps between employer needs, accreditor prescriptions, and undergraduate curricular priorities. Industry and Higher Education, 1-8.

Selvasundaram, K. (2016). An Overview of Empirical Study on Employability Skills. International Journal of Pharmaceutical Sciences Review and Research, 40-45.

Ugochukwu Chinonso Okolie, e. a. (2020). A critical perspective on industry involvement in higher education learning: Enhancing graduates' knowledge and skills for job creation in Nigeria. Industry and Higher Education, 112 . 